\title{
Yûsuf ile Züleyha’nın postmodernizm kavşağındaki yol ayrımı
}

\section{Sezin TÜFEKÇİ KÖROĞLU1}

APA: Tüfekçi Köroğlu, S. (2020). Yûsuf ile Züleyha'nın postmodernizm kavşağındaki yol ayrımı. RumeliDE Dil ve Edebiyat Araştırmaları Dergisi, (18), 179-189. DOI: 10.29000/rumelide.705571.

\section{$\ddot{\mathbf{O z}}$}

20. yüzyılın sonlarına doğru felsefe, sosyoloji, ekonomi gibi birçok disiplinin yanı sıra sanatta ve bilhassa edebiyatta kendini gösteren postmodernizm, günümüzde hâlâ kesin tanımına ulaşmamış bir olgudur. Postmodernizmin bir edebî kuram olarak zamansal ölçütlerle belirlenmesi, sık yaşanılan bir durumdur. Tıpkı 19. yüzyılda kaleme alınmış tüm eserlerin "modern” olduğu ön kabulü gibi, 21. yüzyıla tarihlenen tüm yapıtların da postmodern olduğu kabul edilir genellikle. Oysa tüm edebî kuramlar, kuramsal bir çerçeveye sahiptir ve eserler bu çerçeveye uyumları itibarıyla sinıflandırılmalıdır. Bu çalışmada, Nazan Bekiroğlu'nun ilk kez 2000 yılında okuyucuyla buluşan Yûsuf ile Züleyha adlı eserinin postmodern bir yapıt olup olmadığı kuramsal bakımdan incelenecektir. Eser, kutsal kitaplarda yer alan ve klasik edebiyatta da çokça işlenen bir anlatıyı konu edinmektedir. Tarihî/geleneksel bir konuyu işleyen söz konusu eserde anlatının önceki kaynaklarına da yer yer atıflar yapılmakta, bunun yanı sıra eserin yazım sürecine de değinilmektedir. Bu durum, eserin üstkurmaca, metinlerarasılık ve yeni tarihselcilik gibi postmodern edebiyatta sık kullanılan tekniklerle yazıldığı izlenimi vermektedir. Postmodernizm, bu teknikler aracılığıyla her şeyin yalnızca kurgudan ibaret olduğunu göstermeyi hedeflerken "gerçek"i ontolojik bakımdan reddeder. Söz konusu teknikler önceki anlatılarda verili gerçekleri sorgulamak suretiyle, yeryüzünde özgün bir söz söylemenin olanaksızlığını ve anlatılası tek olgunun kurgusallık olduğunu işaret eder. Bu çalışmada, Yûsuf ile Züleyha'nın söz konusu kuramla uyumu, bilhassa bu "kurgusallı" bakımından sorgulanacak ve ayrı düştüğü hususlar nedenleriyle birlikte tartışılacaktır.

Anahtar kelimeler: Yûsuf ile Züleyha, Nazan Bekiroğlu, postmodernizm, kurgusallık.

\section{The divergence of Yûsuf and Züleyha at the junction of postmodernism}

\begin{abstract}
Postmodernism, proving itself on the fields of art and especially literature as well as many disciplines such as philosophy, sociology, economy towards the end of the2oth century, is a phenomenon that hasn't reached its certain definition. Determining postmodernism as a literary theory with temporal criteria is a common situation. Just as all the works written in the 19th century are presumed to be "modern, all works dated to the 21st century are generally considered postmodern. However, all literary periods have a theoretical framework, and the works should be classified according to their compliance with this framework. In this study, it will be theoretically analyzed whether Nazan Bekiroğlu's book 'Yusuf ile Züleyha', which first met the readers in 2000, is a postmodern work or not.The book tells a story that we see in sacred books and also much -mentioned in classical literature. In this respect, references are made to the previous sources of the story and the writing progress of the work is mentioned as well in the work telling a historical/ traditional subject. This
\end{abstract}

1 Dr. Öğrencisi, İstanbul Medeniyet Üniversitesi, Lisansüstü Eğitim Enstitüsü, Türk Dili ve Edebiyatı ABD (İstanbul, Türkiye), sezinim25@hotmail.com, ORCID ID: 0000-0001-7388-0430 [Makale kayt tarihi: 28.08.2019-kabul tarihi: 20.03.2020; DOI: 10.29000/rumelide.705571] 


\begin{abstract}
situation gives an impression that the story is written with commonly used postmodern techniques such as metafiction, intertextuality and new historicism . Postmodernism denies the truth ontologically, while aiming to show that everything is completely fiction via these techniques. . These techniques, by questioning the facts given in previous narratives ,point out that it is impossible to say an original word and the only phenomenon to be told about is fictionality. In this study, the consistency of Yusuf ile Züleyha with the theory at issue will be questioned especially in terms of this 'fictionality' and the diverging issues will be discussed with reasons.
\end{abstract}

Keywords: Yûsuf ile Züleyha, Nazan Bekiroğlu, postmodernism, fictionality.

\title{
Giriş
}

Yûsuf ile Züleyha, kutsal kitaplar olan Tevrat, İncil ve Kuran-ı Kerim'de yer alan bir hikâyedir. Üstelik Kur'ân-ı Kerîm'de "ahsenü'l-kasas" (kıssaların en güzeli) şeklinde nitelenerek müstakil bir sûrede anlatılmıştır. Kaynă̆ı kutsal kitaplara dayanan anlatı, birçok edebî esere de konu olmuştur. Fars, Keşmir, Afgan ve Urdu edebiyatlarında da kaleme alınmış olan hikâye, Türk edebiyatında en fazla işlenen konulardan biridir. Şeyyad Hamza, Erzurumlu Darîr, Nahîfî, Hatâyî, Taşlıcalı Yahyâ, Gubârî gibi birçok şair, çoğunluğu mesnevi şeklindeki eserlerinde söz konusu anlatıyı işlemiştir. Bunların içinde Hamdullah Hamdi'nin mesnevisi, dil ve anlatı itibariyle özel bir yere sahiptir.

Eski Türk edebiyatında bilhassa mesnevi formunda sıkça işlenen Yûsuf ile Züleyha hikâyesi, Nazan Bekiroğlu tarafından aynı adla modernize edilerek roman formunda kaleme alınmış ve büyük yankı uyandırmıştır. Eserde Kuran-ı Kerim'e ve Hamdullah Hamdi'nin mesnevisine göndermeler bulunması ve eserin metinlerarasılık, üstkurmaca, yeni tarihselcilik gibi postmodern tekniklerle yazıldığı izlenimi uyandırması, bu eser üzerine daha çok eğilmeye vesile olmuştur. Yûsuf ile Züleyha'nın postmodern anlatı teknikleri bakımından incelenmesine yer verilen bu çalışmada, "Postmodernizm" ve Yûsuf ile Züleyha'nın Postmodern Teknikler Bakımından İncelenmesi” başlıklarıyla "üstkurmaca", "metinlerarasılık" ve "tarihe/ geleneğe yönelme" alt başlıklarına yer verilmiştir. Eser, yazar da kurguya katıldığı halde üstkurmaca, başka anlatılara göndermelerde bulunduğu halde metinlerarasılık ve geleneksel/ tarihî bir anlatıyı konu edindiği halde yeni tarihselcilik gibi postmodern tekniklerle yazılmamıştır. Bu tespit, çalışma boyunca nedenleriyle birlikte işaret edilecek ve gerekçeler ortaya konmaya çalışlacaktır.

Çalışma boyunca, Bekiroğlu'nun bu eseri üzerine kaleme alınmış bilimsel yayımlara da atıfta bulunulacak, ancak eserin neden postmodern tekniklerle yazılmadığı ortaya konulmaya çalışılacaktır. Eserleri kuramsal bakımdan incelemek edebiyat tarihi bakımından önemlidir. 13. Yüzyldan bu yana çeşitli coğrafya ve dillerde anlatıla gelen Yûsuf ile Züleyha evrensel anlatısının Bekiroğlu'nun kaleminden dökülen yorumunu kuramsal bakımdan incelemek suretiyle farklı bir bakış açısı getirmek hedeflenmiştir.

\section{Postmodernizm}

"Dünya ne anlamlıdır, ne de anlamsız, vardır o kadar."

Alain Robbe-Grillet (Grillet, 1981, s.37)

Edebiyattan modaya, mimarîden ekonomiye kadar birçok alanda insanlığın postmodern çağını yaşamakta olduğu kabul gören bir gerçektir. Bununla birlikte ve belki tam da bu nedenle, postmodernizmin tanımı şu an için kesinlikten çok uzak görünmektedir. Terim, "çağdaş, çağcıl" 
anlamlarındaki modern kelimesi (Türk Dil Kurumu [TDK], 2019) ile İngilizce "post" önekinin birleşiminden oluşmaktadır. "Post” eki, biri “sonra-sonrası" ve diğeri "eklenti-ekleme” olmak üzere iki farklı anlamı içerir (Erinç, 2019, s. 35). Modernizme tepki mi olduğu ya da onun devamı mı olduğu yönündeki tartışmalar hâlihazırda devam etmekle beraber postmodernizmle ilgili ortak kabul, bu olgunun Batı'da yaşanan derin krizin, Aydınlanma filozoflarının genel çerçevesini çizdiği modern paradigmanın derin bir sarsıntı geçirmesinin sonucu ortaya çıktı̆̆ıdır (Aslan ve Yılmaz, s. 1). İngiliz Tarihçi Toynbee, kitle kültürüyle ilişkilendirdiği postmodernizmin -ilerleme ve akla dayanan modernizmin aksine- irrasyonelliğe ve belirsizliğe dayandığını belirtir (Eliuz, 2016, s. 151). Bilimsel bilginin üstünlüğüne, pozitif bilimlere, doğrusal gelişmeye, ulus-devlet anlayışına, endüstriyalizme, kapitalizme, demokrasiye, laikliğe, insan haklarına, teknolojiye, bürokrasi ve uzmanlaşmaya karşı gelen ve onları sorgulayan postmodernizm; belirsizliğe, parçalılı̆̆a, farklılığa, etniğe, alt-kültürlere, kültürel çoğulculuğa, yerelliğe, özgünlük ve özgürlüklere ayrıcalık tanır (Kızılçelik, 1996, s. 28).

Birlik ve beraberlikten, bütünlükten ziyade çoğulculuğun esas olduğu bu düşüncenin sanata yansıması ise bir araya getirme, bu amaçla derleme ve yeniden bütünleştirmedir. Bir araya gelen parçaların anlamlı bir bütünü işaret etmemesi, hatta anlam, bütünlük, gerçeklik gibi kavramları sorgulayacak şekilde kurgulanması hedeflenir. Postmodern edebiyatta gerçeğe dair sorgulama, Sauusure'ün dilsel göstergenin keyfî doğası hakkındaki temel ilkesine dayanır (Lucy, 2003, s. 47). Saussure'e dayanan dil, diğer bir deyişle anlamlandırma kuramı gerçekliği siler. Çünkü "gerçeklik", dil sistemi içinde hiçbir zaman mevcut değildir. Saussure’ün -Lacan tarafından dil ile gerçekliğin birbirinden kopuk olduğu şeklinde yorumlanan- gösteren/gösterilen ilişkisindeki rastlantısallık ilkesi, dil sisteminin gerçekliği aktarmak ya da göstermekten uzak olduğu, yalnızca gerçeklik gibi işlev gördüğü sonucunu doğurur (Lucy, 2003, s. 49-50). Postmodern edebiyatın kurucu isimlerinden olan Baudrillard'a göre gerçeklik, gerçekdışı olmuştur ve hipergerçekçiliğin simülasyon boyutunu da içermektedir. Artık her yerde gerçekliğin "estetik" sanrısı içinde yaşanmaktadır ( Lucy, 2003, s. 70-88).

Postmodern romana göre "gerçeklik" temsil edilmeyi bekleyen bir veri değil, kurgu sırasında "yaratılan" bir olgudur (Antakyalığlu, 2003, s. 162). Berna Moran postmodern romanın gerçeklikle ilişkisini şöyle ifade eder:

\begin{abstract}
“(...) gerçekçilikten uzaklaşmanın nedeni, yaşamı daha uygun bir yöntemle daha iyi yansıtmak değil, gerçeklikle romanın bağını sorgulamak ve gevșetmek. Postmodern romanın bu özelliği, hiç değilse Batı'da kısmen, modern düşünün getirdiği gerçeklik krizinden kaynaklanır. (...) Bugün modern felsefe, yapısalcllık, göstergebilim ve Derrida'lar çıplak ontolojik olguya da doğrudan doğruya ulaşamayacağımızı, onu ancak dil gibi keyfi gösterge sistemlerinin prizmasından geçirerek algılayabileceğimizi ileri sürüyorlar. Başka bir deyişle, gerçeklik bellediğimiz şey de, bir bakıma kurmacadır.” (Moran, 1994, s. 116, 117.)
\end{abstract}

Edebî eserde gerçekliğe dair sorgulama, kurguyla gerçeklik arasındaki farkın ortadan kaldırılması ve anlatılanların yalnızca bir kurgu olduğunun okura sürekli hatırlatılmasıyla sağlanır.

Türk edebiyatında bazı araştırmacılar tarafından yazarın metnini oluşturma sürecine katmasının ilk örneği olarak gösterilen Müşahedat’ta bunun farklı bir uygulaması görülür (Birinci, 1980: 66-76; Doğan, 2019: 23). Postmodern romanlarda yazar, geleneksel romanlardaki gibi kendi varlığını okuyucuya duyurur ancak bunu yaparken onlarda olduğu gibi inandırıcılı̆̆ sağlamayı değil, aksine bozmayı hedefler. Üstkurmaca tekniği ile kurgu ve gerçeklik arasındaki bağın parodisi yapılırken metinlerarasılık ve yeni tarihselcilik teknikleriyle geleneksel anlatılar ve tarihî gerçeklere dair yeni bir söylem gerçekleştirilir. Postmodern yaklaşım, pastiş ile geçmişe gönderme yaparken parodiyi kullanarak da gelenekle alay eder (Eliuz, 2016, s. 66). Parçalılık ve çoğulculuğu önceleyen, anlam, bütünlük ve 
gerçekliğe yönelik bu yapı-bozum edimi, modern sanatın seçkinciliğine yönelik bir karşıtllğı da beraberinde getirir. Böylece hızla tükenen, popüler bir kitle kültürü şeklinde de görünebilen bir edebiyat profili ortaya çıkar.

\section{Yûsuf ile Züleyha'nın postmodern anlatı teknikleri bakımından incelenmesi}

\section{1. Üstkurmaca}

Postmodern anlatıların en önemli ifade biçimlerinden olan üstkurmaca tekniği ile anlatıcı, metnin içeriğine dâhil olarak metnin kurmaca olduğunu okuyucuya ifşa eder. Bu kurgusallığı göz önünde tutmak için anlatıda metnin yazım sürecine de yer veren yazar, okura meta düzeyden seslenir ve okuyucuyla metnin kurgulanışı üzerine söyleşiye başlar. Böylece gerçek ile kurmaca arasındaki sınırlar ortadan kalkar (Eliuz, 2016, s. 115).

Bekiroğu, Yûsuf ile Züleyha'da "Söz Başı" adlı ilk bölüm ile "Yazıcının Son Sözü” adlı son bölümde yazının kurgulanış sürecini anlatmaktadır. "Söz Başı” başlıklı bölümde yazar “(...) söz de ne senin ne de benim/.../mülk gibi söz de ve aşk da O’ndan...” (Bekiroğlu, 2005, s. 13) sözleriyle anlatıdaki aşk yazgısının da, bu anlatının söze dökülüşünün de kendisine ait olmayıp O'na ait olduğunu söyleyerek eserin hem içeriği hem dile getirilişi üzerine düşüncelerini ifade etmiştir. Bekiroğlu'nun bu ifadeleriyle okuyucuya, ya da kıssanın daha önceki anlatıcılarına ve hatta bizzat Yûsuf ile Züleyha'ya hitap ettiği söylenebilir.

Yazar, ilk bölümün sonunda kitabı yazma sürecini dile getirir:

“Öptüm kitapların da üzerindeki Kitâb’ı, öptüm ve koydum alnıma.

Ben: Yazıcı. Yazmaya başladığımda yıl bin dokuz yüz doksan dokuz milattan sonra, aylardan Nisandı. Bir mumun ışı̆̆ında bir rüzgâr titriyorken. Ve bir hattat nefesinin, bir mumun alevini bile titretmemesi gerekiyorken. Sürgün düştüğüm zamanlarda ben kalbimi çatlatan nefesimi salıverdim.

Ben: Yazıcı. Kalbim çatladığında tanığım su kıyısında bir kavak ağacıydı.

İlk sözler mürekkebi mor kalemimin ucundan dökülürken, Ayasofya’da Topkandilin altında değil idiysem de Hamdullah Hamdi Hazretleri gibi (rahmet onun ve bütün Yûsuf u Züleyha yazıcılarının üzerine olsun), ben de suyun kıyısındaki kentte kendimce bir Ayasofya'daydım. Uyanıklığım, rüyaları yorumlayacak Yûsuf un uyanıklığından farklıydı elbet ama ben de gecenin saat sıfır üçlerinde daima uyanıktım." (Bekiroğlu, 2005, s. 16, 17).

Eserde yazıcıya ayrılan ilk ve son bölümün yanı sıra kurgu boyunca da yazıcının varlı̆̆ı hissettirilir: "Ve dedi ki, öykünün tam burasında, kurdun, kuyunun ve aynanın söylediklerine benzer sözleri diziyor yazıcının kalemi satırlara" (Bekiroğlu, 2005, s. 118) sözleri, olay akışı içinde ifade edilmiştir. Bekiroğlu, "Yazının bedeli vardır bilirsiniz." sözleriyle okura hitap ettiği son bölümde "kimi yazarak öldüm, kimi ölerek yazdım” diyerek yazma sürecini; şu sözlerle de yazma nedenini açıklar: "Anlattılar işte, gözlerimle görmedim, taşlara kazımadım ama yalancı da değilim. Yazılmış bir hikâyenin üzerinden yeniden yazmak arzusuyla geçince yazdım, bu yüzden yazdım.” (Bekiroğlu, 2005, s. 223).

Yukarıdaki ifadelerden de anlaşılacağı üzere yazar, yazıcıyı ve yazma sürecini kurguya dâhil etmiştir. Bu uygulama, postmodern bir teknik olan üstkurmacayı anımsatmakla birlikte bir noktada bu teknikten farklıdır. Yûsuf ile Züleyha'da yazarın kurgudaki varlığı hikâyenin önceki anlatımlarında verili olan kodları ve dolayısıyla gerçeklikle bağları koparmaya, bu suretle kurgusallı̆̆ı ifşa etmeye yönelik değil, aksine önceki anlatılarla hem biçimsel hem de içeriksel bir bağ kurmakYa ve anlatının gerçekçiliğini arttırmaya hizmet etmektedir. 
Söz konusu uygulama eserin gönderge metni olan mesnevi türünün biçim özellikleriyle örtüşmektedir. Eserdeki “Söz Başı” adlı ilk bölüm klasik mesnevilerin önsözü kabul edilen ve mesnevinin yazılış amacını içeren dibace; "Yazıcının Son Sözü" adlı son bölüm ise eserin bittiğini belirten hatime bölümüne yakın görünümdedir. Hamdullah Hamdi Efendi’nin Yûsuf u Züleyha'da yaptığı gibi öykünün kendi imgelemindeki yansımalarına değinen Bekiroğlu, anlatıya Kur'an-ı Kerim ve Hamdullah Hamdi’nin metninde olduğu gibi "Besmele" ile başlamıştır (Eliuz, 2009, s. 123).

Görüldüğü üzere eserin yazıcı sözüyle başlayıp sona ermesi, anlatının gerçek ile bağını koparmamış; bilakis gönderge metinlerden biri olan mesnevi ile uyumunu sağlamıştır. Eserde Postmodern bir edebî teknik olan üstkurmacanın gerektirdiği yabancılaşma izleği görülmemektedir. Postmodernizme göre yazar, anlatılacak hiçbir şeyin kalmadığı bu dünyada ancak metnin kurgu serüvenini anlatabileceğini söyler (Tural, 2018, s. 38). Postmodern eserin asıl konusu kurgunun kendisidir (Antakyalığlu, 2003, s. 161). Oysa söz konusu eserde Bekiroğlu, anlatıya Araf Suresi’nin "Sen onlara bu kıssayı anlat, belki üzerinde düşünürler.” (Kur'an-ı Kerim 7: 176) ayeti ile başlayarak postmodern tutumun tam tersine, üzerinde düşünülesi bir gerçeği anlatmak için yazdığını gösterir. Yazar, eserin gerek yazıcıya ayrılan ilk ve son bölümlerinde ve gerek anlatı boyunca tasavvufî düşüncenin "vahdet-i vücut" anlayışı doğrultusunda hakikati, mutlak ve tek olanı yansıtmıştır. Yazıcının "Her şeyin O'ndan olması ve ışığın tek kaynaktan dağılıyor olması, O’ndan başkasının bilinme ve sevilme ihtimalini tümden yok eder... Yûsuf, Yakub ve Züleyha yok aslında. Hepsi bir, hepsi O bir, hepsi tek bir.” ifadeleri, eserin salt bir kurgusallığı değil, kurguyu ve hatta kurgunun kahramanlarını da kuşatan bir "O” gerçekliğini anlattığının göstergesidir.

Yazar kimliğini herhangi bir gerçekliğin ironisini yapma aracına dönüştürmeyen Bekiroğlu, esasında eserde 'yazar' ifadesini kullanmamış, kendisi için 'yazıcı' nitelemesini tercih etmiştir. Bu tercih, anlattığının 'kurgunun kurmacası' olmayıp bilakis var olan gerçekleri yazdığını işaret ettiği şeklinde yorumlanabilir (Ylldız, 2011, s. 202-203).

Yazar kavramı, roman tarihi boyunca sürekli değişmiştir çünkü zaman içerisinde yazarın kurmacadaki rolü de değişiklik göstermiştir. Anlatma esasına dayalı geleneksel romanlarda yazar kurgu boyunca varlığını sakınmadan hissettirirken gösterme esasına dayalı çağcıl romanlarda artık yazarın bir kusur olarak görülen sesi, anlatının yorumsuz yansıtıldığı izlenimi veren tekniklerle silikleşmiştir. Bu yöndeki uygulamalarla yazarın kurgudaki görünümü değişiklik gösterse de yazarın varlığının tam olarak ortadan kalkması, kurmacanın doğası gereği olanaksızdır. Wayne C. Booth, bu durumu Kurmacanın Retoriği adlı eserinde bir romandaki konu seçiminden sözcük dizilimine, olay örgüsünden bakış açısına kadar birçok unsurun yazarın metindeki varlığını gösteriyor oluşundan hareketle temellendirir (Booth, 2012, s. 31). Kurgu varsa, yazar da vardır. Bekiroğlu'nun söz konusu eserinde kendisi için yazar nitelemesini tercih etmemesinin, anlatının kendi kurgusu olmadığını işaret etmeye yönelik olduğu kabul edilebilir. Bekiroğlu anlatının kurgusunu kendisi inşa etmemiş, kutsal kitaplarda verili olan kurguyu aslına sadık kalarak kaleme almıştır.

Yazar yerine yazıcı kimliğine yönelik bu tercih, postmodern kuramın öncüllerinden olan Roland Barthes’in “yazarın ölümü” tespitinden farklıdır. Postmodern edebi eserde yazarın ölümü, anlatının yazarın kast ettiği tek bir anlamla sabitlenmeyip, her bir okurun kendi imgeleminde yeniden kurgulanabilecek bir çokanlamlılığa sahip olmasını ifade eder (Barthes, 1989, s. 49-55'ten aktaran Nil Göksel). Böylece metin, okur tarafından -alımlanmak ve tüketilmek yerine- yeniden yazılmış ve üretilmiş olur. Bekiroğlu ise kendisinin üstlenmediğini 'yazıcı' kimliğiyle ilan ettiği kurguyu doğal olarak 
okura da bırakmamaktadır. Üstelik Postmodern anlayışın tam tersine çokluk gibi görünen tekliği anlattığını eserin yukarıdaki paragrafta alıntılanan bölümünde açıkça dile getirmiştir.

Bekiroğlu, Yûsuf ile Züleyha adlı eserinin başlangıç ve sonuç bölümlerini kendi yazma sürecine ayırmış olsa da bu durum postmodern bir teknik olan üstkurmaca ile özdeş değildir. Söz konusu eser, üstkurmaca olmak bir yana, kurmaca olmaktan dahi beridir. Nitekim Bekiroğlu, kendisini yazıcı şeklinde nitelemek suretiyle eserin mahiyetinin kurgudan ziyade aktarım olduğunu göstermiş olur. Yazarın yazma sürecinden söz ettiği bölümler, postmodern yaklaşımdan ziyade gönderme yapılan mesnevinin biçim özellikleri ile paralellik göstermektedir.

\section{Metinlerarasılık:}

1960lı yıllardan itibaren edebiyat eleştirisi alanına damga vuran metinlerarasılık kavramı, günümüzde geleneksel söylem ile postmodern söylem arasındaki temel ayrım olarak romanda postmodernliği belirleyen ölçütlerin başında gelmektedir. Metinlerarasıllğı kuramsal olarak ortaya koyan Julia Kristeva, onu bir metnin başka metinlerle ilişki içinde olduğu bir çokseslilik özelliği olarak tanımlar (Aktulum, 2000, s. 11). Metinler arasındaki söz konusu ilişki, bir metinde başka metinlere dair unsurların varlığını gerektirir ancak salt bunların varlığı metinlerarasılık için yeterli değildir. Kristeva'ya göre metinlerarasılık, taklit etmek ya da olduğu gibi alıntılamaktan farklı olarak yer ya da bağlam değiştirme işlemidir (Aktulum, 2000, s. 43). Bir metin asıl bağlamından çıkarılıp yeni bir bağlama yerleştirilirken dönüşüme tabi tutularak yeni bir anlam yüklenmelidir (Aktulum,200o, s. 14). Metinlerarasıllı̆ı sağlayan, metnin alıntılanan ya da taklit edilen başka unsurları kapsaması değil, önceki metinleri bozup bir yeniden dağılım işleminden geçirmesidir (Aktulum, 2000, s. 44). Önceki metinlerin sonraki metinlerde yeni anlamlar kazanmasının sonucu ortaya çıkan çokseslilik ve çokanlamlılık, postmodern romana özgü ayrışıklık özelliğini mümkün kılar.

Yûsuf ile Züleyha hikâyesinin Bekiroğlu tarafından kaleme alınan anlatımı, yüzylllardır anlatıla gelen hikâyenin önceki anlatımlarından beslenerek inşa edilmiştir. Yûsuf ile Züleyha'da yazıcının "Söylenmemiş Mesnevi kalmadı yeryüzünde. Her Yûsuf u Züleyha, bir öncekinin hem aynı hem başkası... Eski zincire bağlanan bir halka, ama yeni (...)” (Bekiroğlu, 2005, s. 16) sözleriyle ifade ettiği üzere eser hem yeniden, hem de yeni bir anlatıdır.

Bekiroğlu, üst metin olan Yûsuf Suresi ve gönderge metin olan -Hamdullah Hamdi’nin- Yûsufu Züleyha mesnevisini içeriği değiştirmeden, yeniden kaleme almıştır. Bununla birlikte biçimsel özelliklerin değişmesiyle ortaya yeni bir anlatı çımıştır.

Yûsuf ile Züleyha, söz konusu anlatılardan farklı olarak roman ile mesnevi arası bir tarzda kaleme alınmıştır. Anlatının konusu çağlar boyu mesnevi şeklinde anlatılagelmiş bir hikâyedir ve Bekiroğlu'nun anlatısı da mesnevi ile olan göbek bağını koparmamıştır: Anlatının bir peygamber kıssası olup belli ahlâki temellere dayanması, "Besmele" ile başlayıp dua ile sona ermesi, klasik mesnevilerin "tahmîd bölümünde olduğu gibi Allah’a övgü ve "tevhîd” bölümünde olduğu gibi Allah’ın birliğinin vurgulanması, eserin mesnevi ile arasındaki bağlara örnek gösterilebilir. Ancak tüm bu benzerliklere rağmen eser mesnevi türünden çok farklı olarak düz yazı şeklinde kaleme alınmıştır. Bununla birlikte Bekiroğlu'nun anlatısı, üslubunun şiirselliği ve içerisine yerleştirilmiş olan gazel ve kasideler ile modern hikâye tarzından da uzaktır. 
Biçimsel farklılıklara rağmen metinde izleksel ya da anlamsal değiştirim yoktur. Yûsuf'un rüyası, Yakub'un Yûsuf'a olan sevgisi ve bunun diğer kardeşler tarafından kıskanılması, kardeşlerinin Yûsufu kuyuya atması, kervancıların onu bulup pazarda satması, Züleyha'nın kendisine köle olarak alınan Yûsuf'a âşı olması, Yûsuf'un bu aşkı reddetmesi, Züleyha'nın kendisini kınayan diğer kadınlar ile yüzleşmesi, Yûsuf'a atılan iftira, Yûsuf'un zindana atılması, Yûsuf'un zindanda Firavun'un rüyasını yorumlaması ve Mısır' a aziz olması, kardeşleri ve babası ile kavuşması gibi olay örgüsünün omurgasını oluşturan tüm bölümler, Kur'an-ı Kerim'deki kıssa ile de Hamdullah Hamdi’nin mesnevisindeki anlatımla da bire bir uyum içindedir (Eliuz, 2009, s. 115-121).

Yazarın "Söz Başı" adlı bölümde, klasik mesnevilerde olduğu gibi diğer yazıcıları anması, "Yazıcının Son Sözü- Yazıcının Rüyası” bölümünde ve anlatının sonunda klasik mesnevilerde olduğu gibi Yûsufun duasına yer vermesi, değişimin içeriksel olmadığını göstermektedir. Söz konusu dua Yûsuf Suresi’nde ve Hamdullah Hamdi’nin mesnevisinde aynıla yer almaktadır (Eliuz, 2009, s. 125).

Bekiroğlu, anlatısını Yûsuf Suresi doğrultusunda kaleme almış, surede anlatılmayan detayları İslam geleneğine uygun şekilde kurgulamıştır. Bekiroğlu, ayrıca, Araf Suresi'nin "Sen onlara bu kıssayı anlat, belki üzerinde düşünürler” (Kur’an-ı Kerim 7: 176) ayetiyle Kur'an-ı Kerim’den doğrudan alıntı yapmıştır. Buna ek olarak 'Yûsuf'un Duası' adlı bölüm, Yûsuf Suresi'nin 101. ayetinin doğrudan alıntılanmasıyla oluşmuştur:

"Ey Rabbim!

Mülkten bana nasibimi verdin

Ve bana rüya ilmini örettin.

Ey gökleri ve yeri yaratan!

Sen dünyada da ahrette de benim sahibimsin.

Beni Müslüman olarak öldür

Ve beni Salihlerin arasına kat” (Kur'an-1 Kerim 12: 101).

Kur'an-ı Kerim'deki ayetlerin bazıları eserin içine anıştırma yoluyla yerleştirilmiştir. İsra Suresi, Kalem Suresi, İnşirah Suresi, Bakara Suresi ve Necm Suresi, yazarın eserin uygun yerlerine eklediği surelerden bazılarıdır (Yıldız, 2011, s. 43-53). Ancak, söz konusu surelerden hiçbiri, eserde bir dönüşüme uğratılmamıştır.

Eserde Türk-İslam geleneğine ait aşk hikâyelerine ve kahramanlarına atıfta bulunulur. Züleyha, gelmiş ve gelecek tüm kadınlara seslenirken bu hikâyelerin kadın kahramanlarını da anar:

“Hanım Hanımcık ol, böyle denecek Leylâ’ya. Ve o da öyle olacak. Çöle düsşen mecnun, Leylâ değil. Leylâ ağlamak için bile bahane bulmak zorunda. Ben öyle miyim ya?

Şirin’in bahtına düşen, uğrunda dağlar delinen olmak olacak, dağları delen değil. Suyu bulmak Ferhad'ın bahtı.

Aslı, en fazla bir âh, felekleri tutuştursa da. Açılıp kapanan düğme Aslı boyundan ayağa. Yanıp küle dönmek Kerem’in hakkı olacak.” (Bekiroğlu, 2005, s. 13).

Yazar, Leyla ile Mecnun, Şirin ile Ferhat ve Aslı ile Kerem anlatılarını Türk-İslam geleneğinde anlatıla gelen formlarını bozmadan, aslına uygun bir şekilde eserine taşımıştır.

Yazar, "Yûsuf'un Kokusu Ruhuna Değdiğinde Yakub’un Hissettikleri"ni dile getirirken Âdem ile Havva’nın birbirlerini yitirmelerinin ardından tekrar bulmalarına, Hz. İbrahim ile $\mathrm{Hz}$. İsmail’in 
teslimiyetlerinin ardından gökten gelen koça, Hz. Eyyüb’ün hastalığı karşısındaki sabrının ardından gelen şifaya, Hz. Yunus'un balığın karnına düşmesinin ardından aydınlığa çıkmasına, Hz. Musa’nın önünde ikiye ayrılıp yol haline gelen Kızıldeniz'e, Hz. Nuh'un tufandan kurtulmasına açık gönderme yapar (Bekiroğlu, 2005, s. 204). Söz konusu göndermelerin tamamında anlatıların geleneksel formuna sadık kalınmış, hiçbiri yapı-bozuma uğratılmamıştır. Bu bölümde Alâaddin’in cini, Mevlâna’nın semaı, İbrahim Edhem'in ceylanı gibi birçok farklı anlatı da geleneğe uygun bir şekilde anılmıştır (Bekiroğlu, 2005, s. 204).

Yukarıda örneklendirilen gönderme, alıntılama ve anıştırmalar postmodern edebiyat anlayışının bir uygulaması olan metinlerasılığı hatırlatsa da bu uygulamalar, metinlerasılık kuramından çok farklı olarak klasik gerçekçi edebiyatın alıntı, telmih ve göndermeleri ile örtüşmektedir. Şecaattin Tural, Modern Türk Edebiyatı’nın 1oo'ü adlı çalışmasında metinlerarasılık ile diğerleri arasındaki farkı şu şekilde açıklar: “...Postmodern bir sanatçı bunu bir teknik olarak kurgusunun temeline koyarken diğerleri düşünce ve duygularını kuvvetlendirmek ve örneklendirmek için yapar.” (Tural, 2018, s. 41).

Metinlerarasılık uygulamasında "yenilik unutuştan ibarettir" anlayışına bağlı olarak (Tural, 2018, s. 41) önceki anlatıların gerçekliği kasten zedelenir, gülünçleştirilir. Örneğin 'parodi' tekniğiyle soylu ve ciddi bir metin genellikle sıradan bir metne uygulanır ya da 'pastiş' tekniğiyle başka bir metnin biçemi taklit edilirken mantık ve simetri yadsınarak içerik değiştirilir (Tural, 2018, s. 41-45). Oysa Bekiroğlu'nun anlatısı, kıssanın ve gönderme yapılan diğer geleneksel anlatıların aktarımlarına yönelik kasıtlı bir zedelemeden çok uzak görünmektedir. Kıssanın önceki söylemlerinin büyük bir kısmı aynıyla alınmış, eklenen kurgular da Türk-İslam geleneğindeki anlatıma uygun olarak tasarlanmıştır. Bekiroğlu, kastının anlatının geleneksel formunu bozmak olmayıp bilakis kuvvetlendirme amacı taşıdı̆̆ını, eserin neden yazıldığına dair açılamaların yer aldı̆̆ı "Söz Başı" bölümünde şu şekilde ifade etmektedir:

"Söylenmemiş Mesnevi kalmadı yer yüzünde. Her Yûsuf u Züleyha, bir öncekinin hem aynı hem başkası(...) böyle olmalı ki sözün hükmü tamam olsun. Eski zincire bağlanan bir halka, ama yeni, böyle olsun ki zincir kuvvetli olsun.” (Bekiroğlu, 2005, s. 204).

Yazarın anlatısına Kur’anı-ı Kerim’den yapılan “Sen onlara bu kıssayı anlat, belki üzerinde düşünürler.” (Kur’an-ı Kerim 7: 176) ayeti ile başlaması, eserin ilahi kitapta "kıssaların en güzeli" şeklinde anlatılan hikâyenin gerçekliğini sorgulamak ya da bozmak değil, üzerinde düşünülmek üzerine yazıldığının göstergesidir. Tüm bunlar, postmodernizmin gerçeklik-kurmaca çatışmasında yazarın tavrının gerçeklikten yana olduğunu göstermektedir.

\section{Tarihsellik/ geleneğe yönelme:}

"Köksüz şeyler daima yüzer, daima beyhude yere bir karış sahil arar. Hâlbuki millî hayat devamdır. Devam ederek değişmek, değişerek devam etmektir. Çünkü yaratmanın ilk şartı devamdır."

(Tanpinar, 2011, s. 24, 25).

19. ve 20. yüzyılın modern dünyasında gelenek kavramına bütünüyle olumsuz bakılmış, geleneğin yerini akıl, ideoloji ve politika almıştır. Yaklaşık olarak aynı dönemlerde, bilhassa Tanzimat sonrasında, benzer eğilimler küçük bir farkla Türk aydınlarında da görülür: Gelenek reddedilir; yerine Batılılaşma düsturu benimsenir. Fakat daha sonra, Tanpınar ve Yahya Kemal gibi kimi aydınlar Batılılaşmayla birlikte geleneği de gerekli görmüş ve bir tür sentezi önermişlerdir. Zamanla Türk aydını yüzünü yeniden geleneğe çevirerek tarihî ve geleneksel anlatıları işleyen eserler kaleme almıştır. Özellikle son yıllarda bu 
eserlerde ciddi bir artış görülmektedir. Bugün için tarih ve gelenek, bilhassa postmodern romanların ana izleklerinden biridir.

Postmodern tavrın tarihe yaklaşımı modernistlerinki gibi redde dayalı olmayıp tamamıyla kurgusaldır. Postmodern roman, üstkurguyla iç içe geçerek tarih yazımının kurgusallığını gözler önüne serer. Bu yaklaşım, Tolstoy ya da Stendal'ın geçmişi detaylı dekoruyla ve bağlamına sadık kalarak yansıtma eğiliminden çok farklı olarak, verili bir anlamın aktarılmasının saçma olduğu, çünkü "anlam”ın da en nihayetinde bir kurgu olduğu esasına dayanır (Antakyalığlu, 2003, s. 164, 165). Hutcheon'un "tarihsel üstkurgu” adını verdiği bu tavır, Nietszsche'nin tarihten mutlak doğru çıabileceğine yönelik şüphesine yakın durur ve okura tarihle olan ilişkisini sorgulatır (Antakyalıŏlu, 2003, s. 166). Postmodern yaklaşımda tarihin bir gerçeklik olarak kabulüne dair sorgulama, hiçbir göstergenin var olmadığı, her şeyin yalnızca bir taklit olduğu kabulüne varır. Çünkü Baudrillard'a göre göstergeler, göndergesel değere sahip olabilmek için belli tarihsel koşullarda var olmalıdır ve bu koşullar artık yoktur. Bu koşulların, yani tarihin yokluğunda artık sadece simulacra vardır (Lucy, 2003, s. 74).

Bekiroğlu, tarihî ve özellikle İslamî geleneği eserlerine taşıma konusunda önde gelen yazarlardandır. Yazar, Nun Masalları, Mücellâ ve Nar A ğacı gibi eserlerinde Osmanlı tarihine yönelmiş, Cam Irmă̆ Taş Gemi'de tarih öncesi dönemi ele almış, Lâ ve Yûsuf ile Züleyha'da peygamber kıssalarını konu edinmiştir. Onun eserlerinde İbn-i Arabi ve Mevlâna gibi mutasavvıfların etkileri, ayetler, hadisler, gazel ve kasideler sıkça yer alır. Bunlar, Türk-İslam geleneğinin kodlarıdır. Bekiroğlu; Ahmet Hamdi Tanpınar, Mustafa Kutlu, Sezai Karakoç, Bahaettin Karakoç gibi geleneğe samimi bir şekilde yönelen ediplerin sanat anlayışına yakın bir duruş sergilemektedir. Bilhassa Mustafa Kutlu ve Bahaettin Karakoç, hem hikâyecilik anlayışının şekillenmesinde hem de hikâyelerinin merkez dergilerde yayımlanması konusunda Bekiroğlu'na destek olmuş yazarlardır. Bekiroğlu, Bahaettin Karakoç’tan ilgi gördüğünü ve bunun özgüvenini arttırdığını dile getirirken, Mustafa Kutlu için "Benim üzerimde çok büyük emeği vardır. Hikâyeciliğimin oluşmasında çok ciddi bir yol göstericidir.” (İliksiz, s. 42-45) ifadelerini kullanmaktadır. Bekiroğlu, "Biz hepimiz onun paltosunun altından çıktık." (Yıldız, 2011, s. 231) sözleriyle Mustafa Kutlu’nun sanatı ile olan ontolojik bağını ortaya koymaktadır.

Ayvaz Beşiroğlu'nun deyişiyle "Tıpkı Yahya Kemal ve Tanpınar gibi tarihin damarlarına sıcakkan yürüte(n) Nazan Bekiroğlu”, postmodern eserlerde olduğu gibi tarihi ve geleneği sıkça kullanmasına rağmen, bunları yalnızca kurgusal ve oyunsal yaratılar olarak ele almaz. Roman yazmak elbette kurgu gerektirecektir ancak Bekiroğlu, bu kurgusallığı tarihî gerçeklerin parodisini yapıp gülünçleştirerek değil, onlara sadık kalmak münasebetiyle inşa eder. Nar Ağacı adlı kurgusal/tarihsel romanına "Şu andan itibaren her şey kurgudur, tarihî gerçekler müstesna” (Bekiroğlu, 2016, s. 7) epizoduyla başlayan yazar, bu sözüyle "tarihî gerçekler"e sadakatini dile getirmiş olur. Oysa postmodern tavır gerçekliğin bizatihi kendisinin ontolojik sorgulamasına dayanır. Yazar, Yûsuf ile Züleyha'da, anlatının geleneksel formuna sadık kalmış, olayları Kur'an-ı Kerim'deki verilişine göre tanzim ederken karakterleri de burada verili kimlikleri doğrultusunda tasvir etmiştir. Üstelik yazar, söz konusu eserin yazılma nedenini açıkladı̆̆ "Söz Başı" bölümünde "eski zincire bağlanan bir halka, ama yeni, böyle olsun ki zincir kuvvetli olsun” sözleriyle gelenek zincirini koparmak ya da oyunsallaştırmak değil, ona eklemlenmek kastı taşıdığını ifade etmektedir. Beşir Ayvazoğlu'nun bu konudaki sözleri Bekiroğlu'nun “zincir”e kattığı kuvveti açıklamaktadır:

“...tülleri aradan kaldırdığınızda, gösterilen dünyanın gerçekliğinden şüphe edilemeyeceğini, başka bir ifadeyle, görüntülerin flûluğuna rağmen, Bekiroğlu'nun kadınca bir duyarlık ve sezgiyle yakaladıklarının gerçeği belgelerden bile daha doğru yansıttığını hissediyorsunuz. Bir minyatürle oryantalist bir gravür arasındaki fark gibi. Gravürlerdeki tasvirler birebir olmalarına rağmen, 
Osmanlı gerçekliğini minyatürler kadar doğru yansıtamaz. Minyatür o dünyanın kendini ifade etmek için geliştirdiği özel bir ifade vasıtasıdır; gravürler ise, görüntülerin orijinallerine benzerliğine rağmen, ressamın bir yığın peşin hükümle yüklü kafasındaki "kurmaca" gerçekliğin yansıtıldığı resimler...”(Ayvazoğlu, 1999).

\section{Sonuç}

Daha önce kaleme alınmış edebî eserlere göndermeler yapma, tarihî olayları ve geleneksel söylemleri konu edinme ve yazarın eseri kurgulayış sürecini esere dâhil etme gibi uygulamalar, eski edebî eserlerden bu yana sıklıkla uygulanagelmiştir. Ancak bu uygulamaların günümüzün postmodern edebî tekniklerinden üstkurmaca, metinlerarasılık ya da yeni tarihselcilikle aralarında önemli bir fark vardır: Kadim eserlerde bu teknikler anlatının gerçekliğini kanıtlamak için kullanılırdı; postmodern tavırda ise sorgulamak için kullanılmaktadır. Postmodern eserlerde söz konusu tekniklerle kurgunun kurgusallığı vurgulanırken "gerçeklik"in ontolojik sorgusu hedeflenir. Yûsuf ile Züleyha, postmodern yaklaşımdan tam olarak bu noktada ayrılmaktadır. Nitekim üstkurmacada olduğu gibi yazar da kurguya dâhil edilmiştir, metinlerarasılıkta olduğu gibi eser başka anlatılara göndermeler içermektedir ve yeni tarihselcilik yaklaşımının gerektirdiği gibi geleneksel/tarihî bir konu işlenmiştir. Ancak, bu uygulamalarla postmodern edebî yaklaşımın kıyısına kadar gelmiş olan yazar, söz konusu tekniklerin ortak özelliği olan "gerçekliğin" reddi hususuna gelince durmuştur. Bekiroğlu'nun her üç postmodern tekniği de kadim hikâyeyi ve hikâyenin işaret ettiği manaları zedelemeden, gerçekliklerine sadık kalarak aktarmak üzere kullandığı görülmektedir. Yeryüzünde söylenmiş ve söylenecek her sözün kurgusallığını ifşa etmeye hizmet eden bu teknikler, Bekiroğlu'nun kurgudan ziyade bir yeniden aktarım olduğunu sıklıkla vurguladığı eserinde mahiyet değiştirmiştir.

Eserde her üç postmodern tekniğin de hikâyenin önceki anlatımlarında verili gerçekliği sorgulamak yerine güçlendirmek üzere kullanılması rastlantı olmaktan uzak görünmektedir. Eser, hikâyenin geleneksel anlatı türü olan mesnevi şeklinde ya da geleneksel klasik roman formunda kaleme alınmamıştır. Mesnevi ile roman karışımı bu eser, günümüz postmodern roman tekniklerini -kendi bünyesine göre dönüştürerek- kullanmak suretiyle çağcıl bir formda kaleme alınmıştır. Yazarın bu tercihinin eserde -yukarıda alıntılanan sözleriyle- ifade ettiği üzere zincirin sağlam olmasına yönelik olduğu söylenebilir. Nitekim Bekiroğlu, zincir metaforuyla kadim hikâyeyi kast ederken kendi anlatısını bu zincire eklenen yeni bir halka olarak niteler ve zincirin ancak böyle -yeni bir halka eklenmek suretiyle- sağlam olacağını dile getirir. Yüzyıllardır geleneksel şekilde söylenegelmiş bu hikâyenin günümüz edebî teknikleriyle kaleme alınması zincirin geçmişi geleceğe bağlayan bugünkü halkasını meydana getirmiştir. Ancak Bekiroğlu'nun günümüz postmodern edebî tekniklerini eserin bünyesine göre dönüştürerek kullanması ve her anlatının ironisini yapmaya dönük bu tekniklerin eserde kadim bir anlatının gerçekliğini desteklemek üzere kullanılmış olması, bu postmodern tekniklerin bizatihi kendisine dair bir ironiyi ortaya çıkarmıştır.

\section{Kaynakça}

Aktulum, K. (2000). Metinlerarası İlişkiler. 2. bs. Ankara: Öteki.

Antakyalıŏlu, Z. (2003). Roman Kuramina Giriş. İstanbul: Ayrıntı.

Aslan S.; Yllmaz A. Modernden postmoderne. http://www. canaktan.org/felsesosyo-tarih/postmodern/modernden-post.htm, ET: 04.05.2019.

Ayvazoğlu, B. Nazan Bekiroğlu, Aksiyon, 1999, http://www.nazanbekiroglu.com/1999/o6/26/besirayvazoglu-nazan-bekiroglu-aksiyon-sayi-238-26-haziran-1999 ET: 21.08.2019.

Barthes, R. "The Death of the Author", The Rustle of Language. çev. Richard Howard, Berkeley: Uni. of California Pres.,1989, s. 49-55'ten aktaran Nil Göksel, Roland Barthes’te Yazarın Ölümü 
Düşüncesi, https://agraphadogmata.wordpress.com/2012/06/23/roland-barthesta-yazarinolumu-dusuncesi ET: 07.08.2019.

Bekiroğlu, N. (2016). Nar A ̆̆acı, 16. bs., İstanbul: Timaş.

Bekiroğlu, N. (2005). Yusuf ile Züleyha, 16. bs. İstanbul: Timaş.

Birinci, N. (1980), "Midhat Efendi’nin Önemli Bir Romanı: Müşahedat”, Kubbealtı Akademi Mecmuası, S. 1, Ocak 1980, s. 66-76.

Booth, W. C. (2012). Kurmacanın Retoriği, çev. Bülent O. Doğan. İstanbul: Metis Eleştiri.

Doğan, M (2019), “Kurmaca ile Gerçeklik Arasında Bir Yazar: Ahmet Mithat Efendi”, Dil ve Edebiyat Araşttrmaları (DEA), Bahar, 2019; (19) 13-36.

Eliuz, Ü. (Temmuz-Aralık 2009). “Geleneğin dirilişi Nazan Bekiroğlu'nun Yusuf ile Züleyha'sı”, Yeni Türk Edebiyatı Araştırmaları, Sayı: 2.

Eliuz, Ü. (2016). Oyunda Oyun Postmodernizm. İstanbul: Kesit.

Erinç,S. M., Postmodernizm'intanımı, https://earsiv.anadolu.edu.tr/xmlui/bitstream/handle/11421/1059/103412.pdf?sequence=1\&is Allowed=y. ET: 04.05.2019.

Grillet, A. R. (1981). Yeni Roman, çev. Asım Bezirci, İstaanbul: Yazko.

İliksiz, Y., Nazan Bekiroğlu: Yasak Meyveyi Havva Yedirmedi, Medcezir, http://www.haber7.com/kultur/haber/382323-nazan-bekiroglu-font-colorffooooyasakmeyveyi-havva-yedirmedifont. ET: 01.08.2019.

Kızılçelik, S. (1996), Postmodernizm Dedikleri. İzmir: Saray.

Lucy, N. (2003). Postmodern Edebiyat Kuramı, çev. Aslıhan Aksoy, İstanbul: Ayrıntı.

Moran, B. (1994). Türk Romanına Eleştirel Bir Bakış-3, 2. bs. İstanbul: İletişim.

Tanpinar, A.H. (2011). Yahya Kemal, 7. bs. İstanbul: Dergâh.

Türk Dil Kurumu. (2019). Erișim Adresi: http://sozluk.gov.tr/(06.05.2019).

Tural, Ş. (2018). Modern Türk Edebiyatının 10öü, Ankara: Otto.

Ylldız, S. (2011). Nazan Bekiroğlu’nun Kurmaca Eserlerinde Geleneğin İzleri (Yüksek Lisans Tezi), İstanbul üniversitesi Sosyal Bilimler Enstitüsü, İstanbul. 